\section{Chapter}

[5]

\title{
Leachate disposal induced groundwater pollution: A threat to drinking water scarcity and its management
}

\author{
Nitin Kamboj ${ }^{1}$, Aditi Bisht ${ }^{1,}$, \\ Vishal Kamboj $^{1}$ and Akanksha Bisht ${ }^{2}$ \\ ${ }^{1}$ Department of Zoology and Environmental Science, Gurukula Kangri (Deemed to be University), \\ Haridwar 249404, Uttarakhand, India \\ Department of Medicinal and Aromatic Plants, High Altitude Plant Physiology Research Centre, \\ H. N.B. Garhwal University, Birla Campus, Srinagar, Uttarakhand, India
}

Abstract

The increasing population over a period of sometime increased the generation of solid waste as well. The process of waste dumping in prehistoric times was very crude as it was disposed of on roads or on the exposed pits in the periphery of the cities. Solid wastes play a lead role in affecting the biotic as well as abiotic components of the surrounding poorly. Until recently, wastes were dumped in the landfill outside the urban area or village boundary where they are burnt or compacted. Dumping and burning of the waste is are not considered an appropriate practice from environmental and human health's point of view. Landfill is the most common mode to remove wastes. The problem linked with landfill is the formation of leachates. The leachates are formed when the waste mixes with the water and penetrates into the ground. The solid waste effect quality of soil, water as well as environment. It is the need of an hour to find the techniques for resource recovery from waste and leachate. This Book chapter discusses in detail about the types of solid waste and leachate their characteristics, techniques of resource recovery from the solid waste and leachate treatment and mitigation methods.

Keywords Hazardous substances, Leachate waste, Solid waste, Waste management

D. Aditi Bisht, Email: minnib18@gmail.com $\left({ }^{*}\right.$ Corresponding author) 


\section{Introduction}

Wastes can be produced during the extraction and processing of resources into intermediate and end products, its consumption etc, and other human activities. Every day to day human activity leaves behind some kind of waste. It is significant to note that solid waste is not substantially constrained to wastes that is physically solid. The production of waste has increased to such an extent that it generates hurdle in the daily lives of today's as well as the future generations (Sharholy et al., 2008). In prehistoric times, garbage was tossed onto the unpaved streets and roadways, where they were left to pile up. It was not till 320 BCE in Athens that the initially known law forbidding this practice was recognized. Shortly this type of system progressed in Greece and the Greek-controlled cities of the eastern Mediterranean. Later during the fall of Rome, waste collection facility declined that persisted throughout the Middle Ages. In the 14th century, scavengers were assumed to perform the duty of dragging waste to landfills outside city walls, but this was not the situation in smaller townships. This went on till the 18th century until when America began the public collection of garbage in Boston, New York, and Philadelphia (Hickman, 2003).

Traditionally, the waste collection was accomplished by sweepers, mostly women. The women used to sweep the streets with the broom and collect the waste in trays (Colon and Fawcett, 2006; Nema, 2004; Malviya et al., 2002; Kansal et al., 1998; Bhide and Shekdar, 1998). The collected waste was then dumped to the nearest storage sites. (Hoornweg and Bhada, 2012). The males generally drive the bullock carts to transfer garbage to the disposal site. In 1994 India faced a nationwide plague epidemic in south-central and western parts of the country. There were flooding in large areas after the sewer were clogged due to heavy rain (Raza, 1997). In 1995 the government of India established a High-Power Committee known as the Bajaj Committee whose crucial characters were the evaluation of the prevailing technologies for municipal solid waste collection, transportation, and dumping. Also, it had to recommend suitable, eco-friendly, and cost-effective technologies options (Joardar, 2000). It was the time when the waste management system was very poor. Technical developments continued throughout the first half of the 20th century. There were two reasonable choices for dumping of the waste and they were either on the land or in the ocean. As now the environmental damage done to oceans by the disposal of waste is well known, the countries decided to ban the dumping of waste in the ocean (Jambeck, 2015). The development of garbage grinders, compaction trucks, and pneumatic collection systems took place during this time. Then later during the mid-century, though, it had become apparent that inappropriate incineration and exposed dumping of solid waste were instigating difficulties of contamination and threatening human health. Therefore, landfills were developed to substitute the exercise of open dumping and to lower the dependence on the burning of the waste (Munawar et al., 2018). The disposal of waste in the landfill is extensively used due to its monetary benefits in relations to the capital costs. In addition to the monetary benefits, landfills allow meticulous 
disintegration of waste to stable end product (Renou et al., 2008). Though, there are certain apprehensions linked to the production of leachate from landfills. The leachates migrate from landfill site to the ground and contaminate the ground water.

Leachate is said to be liquid material that leaches from a waste landfill. They usually comprise of numerous toxins. The composition and content differ with respect to location, composition of waste, $\mathrm{pH}$, moisture, and other characteristics of site (Bove et al., 2015). It consists of suspended and dissolved material. The term leachate is commonly used as landfill leachate. Landfill leachate are the variegated waste with substantial distinction in composition and volume. The amount of production of leachate depends on the climate, age and design of the landfill, degree of compaction and the composition of the waste. In the middle of nineteenth century it was proposed to develop a landfill site with porous underground layer to avoid formation of leachate (Renou et al., 2008). In certain parts of Europe, it was decided to choose sites with engineered lining as landfill. Later United States started developing leachate retentive and gathering systems. This led to the development of multiple lining in all landfills. The waste dumped in the landfill take many years for complete degradation, undergoing physical, chemical, and biological transformation, and then being converting into liquids and gases by the biodegradation process. The leachate produced easily moves into the food chain through the infiltration of soil and surface waters. The presence of leachate into food chain threaten health and environment safety severely. The main type of leachate is landfill leachate, transmission station leachate, leachate due to incineration plants and leachate produced in the waste collection and in the transport process. (Fatta et.al., 1999). The chief sources of leachate from the landfill include precipitation infiltration, surface leachate infiltration, infiltration of ground water, free water in waste, leachate from covering materials and leachate produced from the decomposition of organic matters (He et al., 2015).

The properties of leachate are relied on the components of waste and moisture. For landfill leachate, rainfall is the leading parameter, amongst the features that influence the characteristics of leachate (Aziz et al., 2016). The water of rain enters landfill and transports the pollutants into the liquid from the solid. At the same time, the biological matters in garbage are decayed into soluble organic matters, which then mixes with the leachate under the influence of microorganisms. The leachate in the landfill gets collected at the bottom and penetrates through the soil and later reaches the groundwater (Mor $e t$ al., 2006). The groundwater contamination is prevalent in the areas near landfill since the potential leachate originate from neighbouring dumping site. Due to the increase in population and the effect of landfill leachate on groundwater and soil has led to number of studies recently (Saarela, 2003).

\section{Different types of leachate}

Wastewater is generated in many landfills from various sources both on and off site, including landfill leachate, landfill gas condensate (LFG), wastewater from washing vehicles, drained free liquids, 
stormwater, contaminated groundwater, wastewater from laboratories, washing floors etc. These different types of leachates are discussed in this section.

Landfill leachate: Leachate from a dumping site differs extensively in composition. It generally comprises of suspended solids. They are produced chiefly by rainfall saturating the waste collected in the landfill. Once the water comes in interaction with decomposing solid waste, the water becomes polluted, and after getting contaminated flows out of the waste known as leachate (Washington State Department of Ecology). Further the volume of leachate is twisted through the breakdown of carbonaceous material manufacturing a variety of other resources like methane, carbon dioxide, aldehydes, alcohols and simple sugars (Nika et al., 2020). The risks of leachate production can be eased by accurately engineered landfill spot, like those that are built on geologically impervious materials that use resistant linings made of engineered clay. Use of Such liners are compulsory in United States, Australia, and European Union apart from the places where waste is believed to be inactive (Mishra et al., 2018). Moreover, utmost poisonous and difficult materials are now specially excluded from landfilling. Nevertheless, in spite of much stringent legal control, leachates from the dumping sites are frequently found to comprise a variety of contaminants coming from unlawful activity and domestic products (Renou, 2008). Landfill leachate comprises of wastewater that is seeped from the compact waste stacked up on the landfill. This liquid may be rainfall that has sieved through the pile of waste or it may be any kind of liquid or moisture that has originated from the waste itself (Raghab, 2013). Generally, it is a mixture of both and contains suspended contaminants that were detached from the garbage as it passed through the solid waste material. This waste water can possibly travel into the wider environment over a period of time. As liquid travels through a landfill, it can seep elements of concern that are found in the waste pile, transporting them deeper into the substrate. This poses a probable ecological and public health risk as both soils and groundwater can become contaminated (Klinck and Stuart, 1999).

Landfill gas condensate: Landfill gas condensate is formed when a liquid condenses in the landfill gas collection system as gas is extracted from the landfill (Zhao, 2012).). Hazardous gases such as methane and carbon dioxide are produced by microorganisms as they breakdown the garbage on the landfill. These gases produced in the landfill need to be removed to avoid the build-up of gases that can result in explosion on and off site (Fjelsted, 2020).

Industrial leachate: Leachate is produced in a landfill or a land that is polluted by the chemicals or toxic waste of the industrial activities like godowns, storage locations, factories, mines, manufacturing plants etc. Composting sites having high precipitation also produce leachate (Gotvajn et al., 2009; Turan et al., 2011).

Mining leachate: Leachate which is associated with various mining activities comes under leachate mining. The stockpiled coal, waste materials of metal ore, waste from rock mining procedures (Botelho, 2018). 
Leachate from concrete: In terms of civil engineering (more specifically reinforced concrete design), leachate is formed by washing off of the concrete material or infuses through the cement, thus catalysing its oxidation and disintegration. This type of leachates cause defect in genes also known as genotoxicity due to physical and chemical agents (Singh, 2007).

\section{General characteristics of leachates}

The characteristics of leachate is dependent profoundly on numerous factors such as composition and the age of waste, degree of decomposition, procedure of waste-filling, waste moisture content and temperature (Armstrong and Rowe, 1999). The amount and nature of leachate is extremely inconstant (Purwanta, 2007). The chief pollutants in the leachate is ammonia and organic matter, but if the age of landfill increases, the concentration of organic matter in leachate also decreases (Kulikowska and Kilimiuk, 2008).Toxicity and health hazards due to wastewater are firmly administered by their composition in comparison to the set permissive levels for the environment (Bhalla et al., 2013). Leachate can also be characterized as a type of wastewater due to its relative variability of composition (Ehrig and Robinson, 2011). This variability is a result of many site-specific parameters like climate, geography, design of the landfill, and composition of the waste, but also the regulatory measures and management practices applied. For the Evaluation of risks associated with leachate, it is mandatory to understand attenuation of leachate in aquifers entering the groundwater, for interpretation of groundwater samples from monitoring of the wells, and for determining suitable curative action, together with monitoring natural attenuations (Christensen et al., 2001). The initial stage is aerobic degradation of organic matter which is usually short. When the oxygen is depleted, degradation continues anaerobically. The process of anaerobic degradation comprises of two main fermentation stages i.e. the acidogenic phase which produce a young biodegradable leachate, and the methanogenic phase which generate stabilized old leachates (Welander, 1998). Leachate composition becomes complex when industrial waste is mixed with municipal solid waste in the landfill, because of the suspension of contaminants in the industrial wastes (Lee et el., 2010). The leachate found in incineration plants and transfer stations is relatively different to that found in landfill. The following are the few characteristics of leachate.

Colour and odour: Leachate display brown, black or dark brown as it has high contrast, with a pungent smell.

$p H$ : The landfill shows weak acidity of $\mathrm{pH}$ value between 6 and 7 at the primary stage. Later when the landfill stabilizes the $\mathrm{pH}$ between 7 and 8 .

Organic compounds: Numerous organic compounds, organic acids, aromatic hydrocarbons, alkanes and alkenes, phenols, ketones, lipids, alcohols, aldehydes and amides are found in leachate. These organic substances may be carcinogenic or may contain blacklist priority pollutants. 
Xenobiotic organic compounds (XOCs): The concentration of xenobiotic organic compounds varies because of the differences amid the landfill as well as the composition of waste and also the time of landfill. The common XOCs are tetrachloroethylene, trichloroethylene, toluene, benzene, ethylbenzene, and xylene. In the leachate sometimes phenoxy acid herbicide has also been detected.

Ammoniacal nitrogen: The half mature leachate contains high concentration of ammonia-nitrogen. The hydrolysis and fermentation of nitrogenous organic substances increases the difficulty of ammonia nitrogen elimination process. In the landfill site during methanation stage the concentration of pollutant increases as most of the landfill sites uses anaerobic technology. The concentration of ammoniacal nitrogen $\left(\mathrm{NH}_{3}-\mathrm{N}\right)$ is higher in the stable stage.

Phosphorus: The concentration of phosphorus is low in leachate, especially of dissolved phosphate, irrespective of its source.

Heavy metals: Amongst the numerous contaminants in leachate, the metallic ions, specifically, heavy metal, should be paid more attention as they are harmful to the environment and the effect on the biological treatment. There are various types of heavy metal ions in the leachate. The insoluble metals are converted into soluble metal and later mix in the leachate through various physical and chemical reactions.

Total dissolved solids: There is high concentration of total dissolved solids found in the leachate. Normally, the maximum range is reached within 15 months. Also, it comprises a high concentration of $\mathrm{Na}, \mathrm{K}, \mathrm{Cl}, \mathrm{SO}_{4}$, and other inorganic salts, which will steadily deteriorate until the ultimate stability of landfill. Because of the consumption habits of Asians, the potassium, sodium and chlorine content are fairly higher in the Asia landfills; so, it is better to have a pre-treatment prior to the biological treatment. Commonly, a 10-year matured leachate comprises of 100-400 mg/L of sodium, 50-400 mg/ of potassium and $100-400 \mathrm{mg} / \mathrm{L}$ of chlorine, but in Asia the concentrations are 1500-5640 mg/L, 400-1940 mg/L, and 875-2900 mg/L, respectively.

Microorganisms: Microorganisms like nitrite bacteria, nitrifying bacteria, denitrifying bacteria, desulphobacter, thiobacillus denitrificans, iron bacteria, sulphate reducing bacteria, methanogenic bacteria, pathogenic bacteria, and pathogenic microorganisms are found in large number in leachate. They play a vital role in the degradation of leachate. Moreover, the high concentrations of ammonia nitrogen and heavy metal creates an unevenness of microbial nutrients, which hinders the growth and regeneration of microbes. The common bacteria in the leachate are Corynebacterium, streptococcus, Achromobacter, granular bacteria, aerobic bacteria, Clostridium etc.

\section{Solid waste disposal and leachate formation}

Landfill of solid waste may cause serious ecological effects if the emission of gases and leachate are not administered. A clear-cut understanding of the amounts and physical characteristics of the waste being 
produced is a crucial element in the growth of tough and cost-efficient solid waste management approaches. Even Though complete or reliable evidence is absent, at the country level, a few broad trends and widespread features are noticeable. In general, the developed countries produce much greater amounts of garbage per capita related to the developing countries (Hwang, 2007). However, in some situations, the management of even minor amounts of waste is a considerable task. Many countries have categorized waste into two categories, i.e. hazardous and non-hazardous. But generally, the solid waste is divided into municipal solid waste, industrial waste, agricultural waste, and hazardous waste (Figure 1). The types of waste are given below:

Municipal solid waste (MSW): The terminology municipal solid waste (MSW) is usually used to define most of the non-hazardous solid waste from an urban area or village that needs routine gathering and transportation to a processing and dumping site (Kumar et al., 2016). The MSW is collected from households, business-related organizations, and institutions, as well as industries. Though, MSW does not comprise waste from industrial practices, sewage sludge building, and demolition debris, mining, or agronomic wastes. It is also described as trash or garbage.

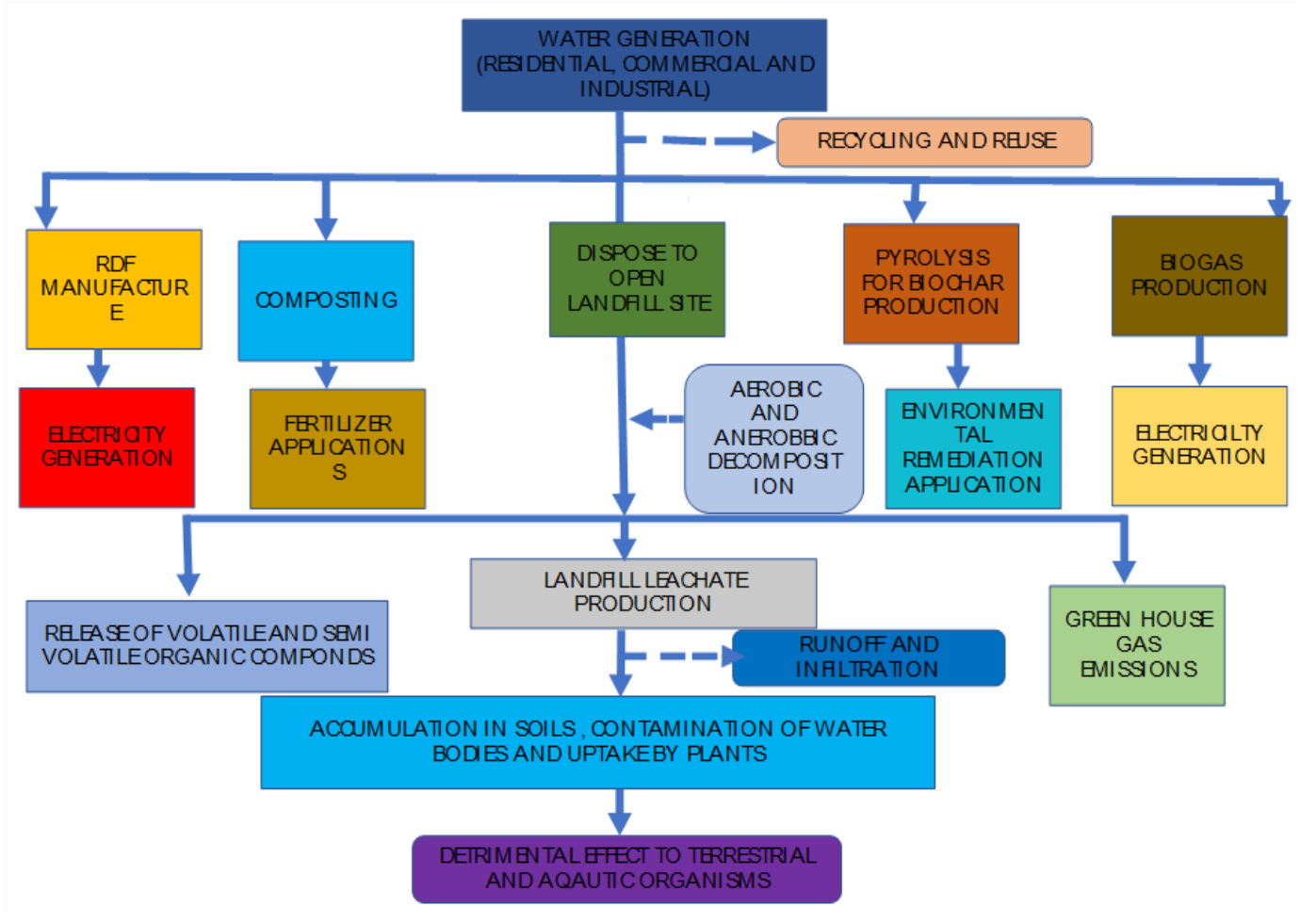

Figure 1. Flow-diagram showing the formation of leachate from different wastes. 
Commonly domestic waste and MSW are treated as substitutes (Cheng and Hu, 2010). Municipal solid waste comprises a large variety of items. It may include food waste like vegetable and meat leftover, unused food, eggshells, etc, which is categorized as wet waste as well as paper, newspaper, glass bottles, plastic bags, plastic canisters, packaging boxes, aluminium foil, wood pieces, etc., are classified as dry garbage (Joardar, 2000; Singh et al., 2011). The population of the urban area in India is expected to increase from the existing 350 million to about 600 million by 2030. The challenge of controlling municipal solid waste (MSW) in an ecologically and efficiently viable approach is destined to accept gigantic proportions. State-wise and union territory generation, collection, and treatment data by CPCB of 2016 are given in Table.

As the towns and cities are growing in size with an increase in the population, the quantity of waste generated is also becoming uncontrollable. The local corporations have adapted diverse approaches for the waste disposal like open dumps, sanitary landfills, landfills, incineration plants and composting.

Agricultural wastes: The waste produced by farming comprises waste from crops and cattle. In developing countries, this type of waste does not create severe trouble as most of it can be utilized e.g., dung is used for compost, hay is used as feed. Agrarian wastes are rice husk, degasses, nutshells, straw of cereals, maize cobs, etc. (Agamuthu, 2009). Agriculture waste can be categorized into field waste and process waste. Field wastes are remains that are left in the field after the crop harvesting. These residues are seed pods, stalks, leaves, and stems. The process wastes are leftover found in the field even after the crop is transformed into a valuable product. Example molasses, bagasse, husks, seeds, stem, straw, stalk, leaves, shell, pulp, peel, stubble, roots, etc. and used for animal feed, fertilizers, soil improvement, manufacturing, and various other processes (Jecu, 2000). India produces about 350 million tonnes of agrarian waste each year. In 2015 the ministry of renewable energy estimated the $18,000 \mathrm{MW}$ of power can be generated from this waste apart from the organic manure for the field. Composting is also one of the best choices for disposal of agriculture waste as it become nutrient rich fertilizer. Other waste disposal methods are land filling, piling, burning, dumping etc. Some of these methods help in recycling and recovery of the nutrients but some process cause pollution of environment and resources (Kumar et al., 2020a).

Bio-medical wastes: Bio-medical waste implies any waste, produced through the diagnosis, medication, or vaccination of individuals or animals. It also includes the animals involved in research events concerning there to or in the manufacture or testing of medications (Ezirim et al., 2018). According to study Associated Chambers of Commerce and Industry of India (ASSOCHAM) and Velocity, India is expected to produce nearly 775.5 tonnes per day of medical waste by 2022 from the existing amount of 550.9 tonnes daily. But the COVID 19 pandemic has increased this burden to an unexpected level. Earlier 500 grams of medical waste was produced per bed but during COVID this went up to 2.5 to $4 \mathrm{~kg}$ daily. Also, a COVID hospital produces approx. 1800-2200kg medical waste each day which includes gloves, PPE kit, masks, shields etc. According to the government instructions, PPEs 
like masks and gloves generated are mandatory to stock separately for a minimum 72 hours for discarding along with waste after shredding. Also, the shredded masks and gloves from residential area can be collected as dry waste by Local Bodies Various common methods for treatment and disposal of medical waste are incineration, autoclaves, chemical disinfection, microwave, irradiation and vitrification. The sufficiently sterile waste which is treated can be disposed with other waste in a landfill, or in few cases discharged into the sewer system. Earlier, the waste was treated on the hospital site itself but now new regulations have developed which allow workers to gather, treat, and dispose the waste.

Industrial wastes: Industrial waste is the toxic waste released by food processing businesses, metallurgical chemical and pharmaceutical companies, sugar mills, paper, and pulp industries, fertilizer, and pesticide industries (Skrinde and Bhagat, 1982). These toxins require special handling (Gyawali et al., 2012). India generates about 7.46 million metric tonnes of hazardous waste generated from more than 40,000 industries (ASSOCHAM, 2017). While disposing this type of waste, it must be classified into three categories on the basis of method of waste disposal. Three methods are incineration, land disposal and underground injection.

Hazardous wastes: Hazardous wastes are those which harm the human and the natural environment (Orloff et al., 2003). Wastes are categorized as harmful if they display four primaries characterises like toxicity, reactivity ignitability, and corrosively based on physical or chemical properties (Malviya et al., 2006). Hazardous waste is also of five types:

- Toxic wastes: Toxic wastes are those that are toxic in minor or trace quantities. A Few may have acute other may have a negligible effect on humans and the environment (Hamilton, 1985). Prolonged exposure in some amount sometimes leads to carcinogenic or mutagenic effects. Examples of pesticides, heavy metals.

- Reactive wastes: Reactive wastes tend to alter actively with air or water. They are volatile generally when encounter the heat (Lussiez, 1993). Examples: Gun powder, nitroglycerine.

- Ignitable wastes: Ignitable waste is those that burn up at reasonably low temperatures $\left(<60{ }^{\circ} \mathrm{C}\right)$ and are capable of spontaneous ignition during storage, transportation, or dumping. Examples: Gasoline, paint thinners, and alcohol (Schoenberger et al., 1984).

- Corrosive wastes: Corrosive wastes are those that damage objects by chemical reactions. Examples: acids and base (Lee et al., 2007).

- Infectious wastes: Infectious wastes are the human tissue from a surgical procedure, utilized bandages, needles, and other hospital wastes (Sawhill et al., 1995). Generation of leachate is a chief concern for municipal solid waste (MSW) landfills and causes substantial risk to surface and groundwater. The leachate produced in the landfill consists of large quantities of organic and in organic pollutants (Kettunen and Rintala, 1998). Even though this type of waste was thrown in 
landfills in olden times, which caused the adjacent atmosphere to be polluted with hazardous substances. Presently, only few hazardous wastes can be dumped into landfills, but only if they are first solidified and stabilized. Numerous harmful wastes can be recycled, batteries, circuit boards, fluorescent tubes, mobile phones, etc. Other approaches of hazardous waste disposal include incineration also known as waste-to-energy, second is pyrolysis, and third is isolated landfills used explicitly for harmful waste (Table 1).

Table 1. Statistics of solid waste generation and collection in India (CPCB, 2016).

\begin{tabular}{|c|c|c|}
\hline State/Union Territory* & Generated (tons per day) & Collected (tons per day) \\
\hline Andaman and Nicobar* & 70 & 70 \\
\hline Andhra Pradesh & 4760 & 4287 \\
\hline Arunachal Pradesh & 116 & 70.5 \\
\hline Assam & 650 & 650 \\
\hline Bihar & 1670 & - \\
\hline Chandigarh* & 370 & 360 \\
\hline Chhattisgarh & 1896 & 1704 \\
\hline Daman Diu and Dadra* & 85 & 85 \\
\hline Delhi $^{*}$ & 8370 & 8300 \\
\hline Goa & 450 & 400 \\
\hline Gujarat & 9988 & 9882 \\
\hline Haryana & 3103 & 3103 \\
\hline Himachal Pradesh & 276 & 207 \\
\hline Jammu and Kashmir* & 1792 & 1322 \\
\hline Jharkhand & 3570 & 3570 \\
\hline Karnataka & 8697 & 7288 \\
\hline Kerala & 1339 & 655 \\
\hline Lakshadweep* & 21 & - \\
\hline Madhya Pradesh & 6678 & 4351 \\
\hline Maharashtra & 22,570 & 22,570 \\
\hline Manipur & 176 & 125 \\
\hline Meghalaya & 208 & 175 \\
\hline Mizoram & 552 & 276 \\
\hline Nagaland & 344 & 193 \\
\hline Orissa & 2374 & 2167 \\
\hline Puducherry* & 495 & 485 \\
\hline Punjab & 4105 & 3853 \\
\hline Rajasthan & 5037 & 2491 \\
\hline Sikkim & 49 & 49 \\
\hline Tamil Nadu & 14500 & 14234 \\
\hline Tripura & 415 & 368 \\
\hline Telangana & 6740 & 6369 \\
\hline Uttar Pradesh & 19180 & 19180 \\
\hline Uttarakhand & 918 & 918 \\
\hline West Bengal & 9500 & 8075 \\
\hline Total & $1.41,064$ & $1,27,832.5$ \\
\hline
\end{tabular}


Leachate is an outcome of precipitation or the moisture present in the landfill with the waste. It also has a high concentration of metals and few harmful organic substances. The elimination of these organic solids on the basis of COD, BOD and ammonium from leachate is the common requirement before discharging the leachates into waters (Kettunen et al., 2009). The configuration of leachate from the dumping ground may differ depending on numerous features in the waste such as degree of compaction, like composition, climate and moisture content. When water penetrates through the litter, it helps and supports the procedure of disintegration of waste by bacteria and fungi. These procedures in turn release by-products and quickly utilize available oxygen, forming oxygen free atmosphere. In actively decaying waste, the temperature increases and the $\mathrm{pH}$ reduces quickly with the outcome that several metallic ions that are fairly insoluble at neutral $\mathrm{pH}$ become dissolved in the formation of leachate. The processes of decomposition discharge more water, which enhances the volume of leachate. Leachate also responds to the materials that are not susceptible to decay themselves, such as building supplies, gypsum-based materials and ash which change the chemical composition. In places where we can find huge amount of construction waste, specifically those gypsum, the reaction of leachate can produce huge volumes of hydrogen sulphide. This hydrogen sulphide may be released in the leachate and also become a big part of the landfill gas. The appearance of leachate is black, yellow or orange coloured gloomy liquid with strong odour when emerge from a typical landfill site. Due to the hydrogen, nitrogen and sulphur-rich organic species the smell is acidic and offensive (Mor et al., 2006).

In a landfill that collects a variety of commercial, municipal, and industrial waste but eliminates substantial volumes of concentrated chemical waste, landfill leachate may be considered as a water-based solution of four groups of contaminants: dissolved organic matter such as alcohols, acids, aldehydes, short chain sugars etc.; inorganic macro components like common cations and anions including sulphate, chloride, iron, aluminium, zinc and ammonia; heavy metals example $\mathrm{Pb}, \mathrm{Ni}, \mathrm{Cu}$, $\mathrm{Hg}$; and xenobiotic organic compounds such as PCBs, dioxins etc. (Kjeldsen, 2002). A large amount of multifaceted organic pollutants have also been found in landfill leachates.

\section{Impacts of leachate and solid wastes on the environment}

Municipal solid wastes pile up on the streets due to inadequate disposal system. People clean their own homes and litter their environments which alters the vicinity including themselves. This type of dumping permits biodegradable items to decay under unrestrained and unsanitary circumstances (El-Fadel et al., 1997). This produces obscene odour and breeds a variety of insects and infectious creatures besides ruining the aesthetics of the place. Industrialized solid wastes are sources of toxic metals and hazardous wastes, which may spread on land and can initiate variations in physicochemical 
and biological traits thus altering the efficiency of soils. Toxic materials may percolate to pollute the ground water (Havlicek et al., 1971). In refuse mixing, the hazardous wastes are combined with trash and other inflammable wastes. This makes separation and discarding complicated and dangerous.

Environmental standards are met by few landfills in the world. The decomposing garbage release methane gas which is a chief environmental concern these days. Methane is the by-product of the anaerobic respiration of bacteria, and these microbes flourish in landfills with high quantities of moisture. At high anaerobic decomposition, the methane concentration can reach up to $50 \%$ of landfill gas. Additional problem linked with these gases is their contribution to the greenhouse gas effect and climate change. There is a difference in the leachate management in the landfills of the developing countries, a thick sand deposit is used at the bottommost of waste pits, fixed with plastic sheet liners to circumvent penetration of liquid into the adjacent soil. Therefore, instead of infiltration evaporation is encouraged. The group of people at risk because of the unscientific dumping of the solid waste are the pre-school kids; labours working in dumping location; and employees in services manufacturing poisonous and infectious material. Other risky zone includes inhabitants living nearby a dumping site and those who consume the water which gets contaminated due to dumping of waste from landfill sites. The uncollected solid waste also increases the risk of diseases, and infections.

Organic waste specifically poses a serious threat, producing circumstances favourable to the existence and development of microbial pathogens. The handling of solid waste directly can result in numerous chronic diseases and types of infectious in which rag pickers and waste workers are most vulnerable. Serious danger on well-being is caused by waste from agriculture and industries. Discarding of harmful waste of industries with community waste can expose public to chemical and radioactive hazards. The solid waste which is not collected sometimes hinder runoff water, resultant in the establishing of still water bodies that become the breeding ground of disease. Waste discarded near a river also contaminate the water source. Dumping of untreated waste directly into the seas, rivers, and lakes results in the gathering of toxic matters in the food web through the plants and animals. Dumping of hospital waste requires special care since this can produce major health hazards. This waste generated from the hospitals, and other health centres like syringe needles, bandages, cotton, plaster, and other types of infectious waste are often disposed with the regular non-infectious waste (Alam and Ahmade, 2013). The sites where wastes are disposed and treated cause health risks for the surroundings. The incineration plants are not properly run also cause air pollution and inappropriately managed and planned landfills attract all kinds of bugs and rodents that spread disease (Hester and Harrison, 2002). Preferably these sites should be situated at a harmless distance from all anthropological settlement. They should be lined so that it should not seep underground. There is a health risk in recycling as well if suitable safeguards are not followed. Employees may face toxic exposure working with waste comprising chemical and metals (Reinhart and Basel, 1996). Removal of health-care wastes need special care since it can create major health hazards, such as Hepatitis B and C, through discarded needles. Rag 
pickers and others who are involved in searching recyclable material from waste, may get wounds and come into direct contact with these infectious items.

\section{Techniques of resource recovery from the solid waste and leachate treatment}

The world is facing the rising rates of petroleum and its products, scarcity of electrical energy supply, degradation of the environment, and accessibility of millions of tons of biomass. The Research and Development events in the field of bioenergy including bioethanol, bio methanation, biodiesel, biomass gasification, biomass cookstove, etc. is receiving a lot of attention and consideration throughout the world (Fassell, 1977). The Government of India has started the combination of $5 \%$ ethanol in the gasoline, thinking about the increasing fuel demand. It is also expected by the Jatropha Mission at least $10 \%$ of the liquid fuel that can be used in the transportation sector can be replaced. Likewise, the Ministry of New and Renewable Energy (MNRE) has introduced the distribution of advanced biomass cookstoves in the 12th five-year plan out of carbon expenditure. The evolution of renewable energy usually promotes energy divergence, in terms of the technology portfolio and geographic sources. It can also diminish fuel imports and shield our economy to from fossil fuel price fluctuation (Figure 2).

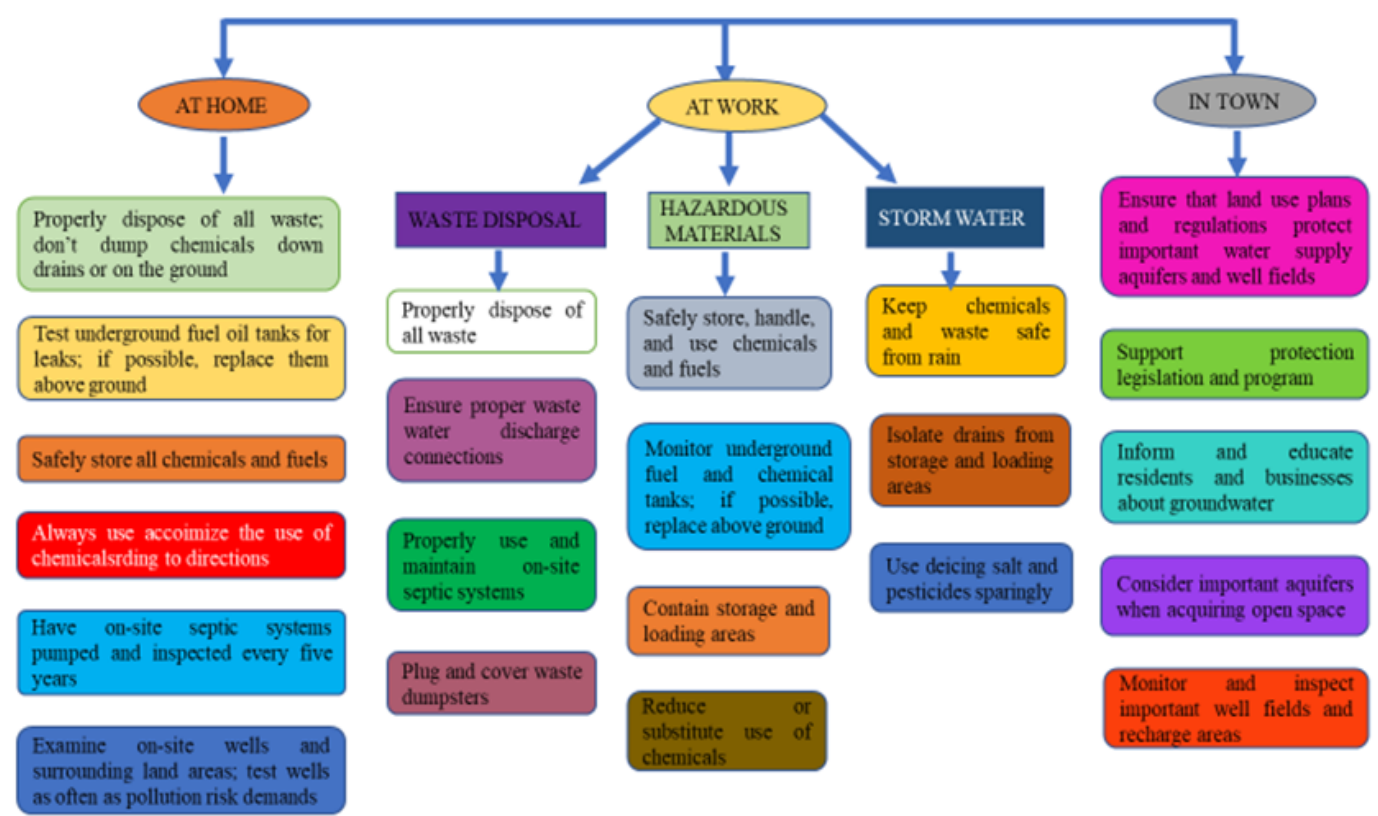

Figure 2. Mitigation measures of ground water pollution caused by leachate disposal. 
The processes of transforming garbage into energy is an evolving and inventive development of technologies designed to generate a safer and sustainable environment. The emerging technique to form energy from waste is a safer technique to protect our Environment. It is believed to resolve the energy crisis of the globe. Although the level of energy production using waste to energy approach is still insignificant right now, it can be a great solution for the energy needs in the future (Lens et al., 2004). In this chapter, we will deal with the common techniques used for energy generation. The process is commonly divided into two categories i.e. Thermal Technologies and Non-Thermal Technologies .

\section{Thermal technologies}

Gasification: Single most prevalent thermal technologies, gasification can simply transform low-value feedstocks into high-value commodities. In this method, carbonaceous materials are transformed into carbon dioxide, carbon mono oxide, and a little quantity of hydrogen at an elevated temperature in the presence of oxygen. Synthesis gas is produced in the process which is a great type of alternative energy. This gas is utilized to generate electricity and heat (Figure 2). The green energy source is given for fertilizers, fuels, baseload electricity, and chemicals through this technology. This will lower the country's reliance on natural gas and oil. The fuel produced by this process can be carried and collected effortlessly. Gasification technology is even now being employed by the energy, refining, chemicals, and fertilizers industries. Some industries like Royal Dutch Shell, Siemens Energy, etc have made an enormous investment in this technology.

Depolymerization: One of the best ways to deal with plastic waste is depolymerization technology. In this technique, the waste is converted into liquid energy like fuel oil. One key benefit of depolymerization is that it converts all heavy metals found in the garbage into stable oxides. The depolymerization technology employs thermal decomposition in the presence of water. Here, the organic complexes present in the waste are heated at a high degree temperature to generate thermal energy. We can make fossil fuels from the waste using this technique (Adams et al., 2010). The method of thermal decomposition is also termed as Hydrous Pyrolysis.

Pyrolysis: Pyrolysis is a thermal process that decomposes organic matter with no use of oxygen. Products like coal, cardboard, paper, plastic, rubber, human waste, and are used in this procedure. Like gasification, pyrolysis facilitates in lowering the amount number of carbon emissions. This processed product like char that carry to the carbon of biomass which therefore makes it appropriate for enhancing soil efficiency (Chen, 2014). Most Recently this technique has also been utilized to produce bio-oil from biomass. This is also very useful in treating drained sludges. The heat produced in this process is divided into three kinds, based on its utilization. First is the heat which can be used for moisture vaporization, second denotes the calorific necessity of pyrolysis, whereas third is the energy loss throughout the process (Weng et al., 2013, Boukis et al., 2007). The greatest benefit of pyrolysis over 
incineration very less impact on the environment in terms of air pollution. Even Though, preliminary expense and procedure price is high which is making this method challenging to appear commercially.

\section{Non-thermal technologies}

Fermentation and anaerobic digestion are the two non-thermal technologies which that are widely used to reduce the greenhouse effect. These are regarded as the finest substitutes for fossil fuels. Developing countries are using non-thermal technologies to make low energy solutions (Figure 3-5).

Fermentation: The procedure that uses yeast and natural microorganisms to manufacture ethanol, involving a series of chemical reactions like hydrolysis, distillation, etc. is known as fermentation. With the ever-increasing population and consumerism, managing waste has come to be an essential part of sustainable development. Thus, transforming garbage into energy is a blessing that can not only improve the standard of living but also help maintain the environmental balance that is very critical. The product which we get at the end of the process is ethanol, it can be combined with gasoline and utilized in motor vehicles (Hay et al., 2013).

Anaerobic digestion: The process of anaerobic digestion can either one take place in nature or in a digester. The digester is heated airtight and airless vessel, which encourages microbes (bacteria) to ferment litter consisting of organic waste like animal waste and slurries to generate biogas (Kumar et al., 2020b). It is the method that produces biogas when the garbage is left untouched (Figure 3).

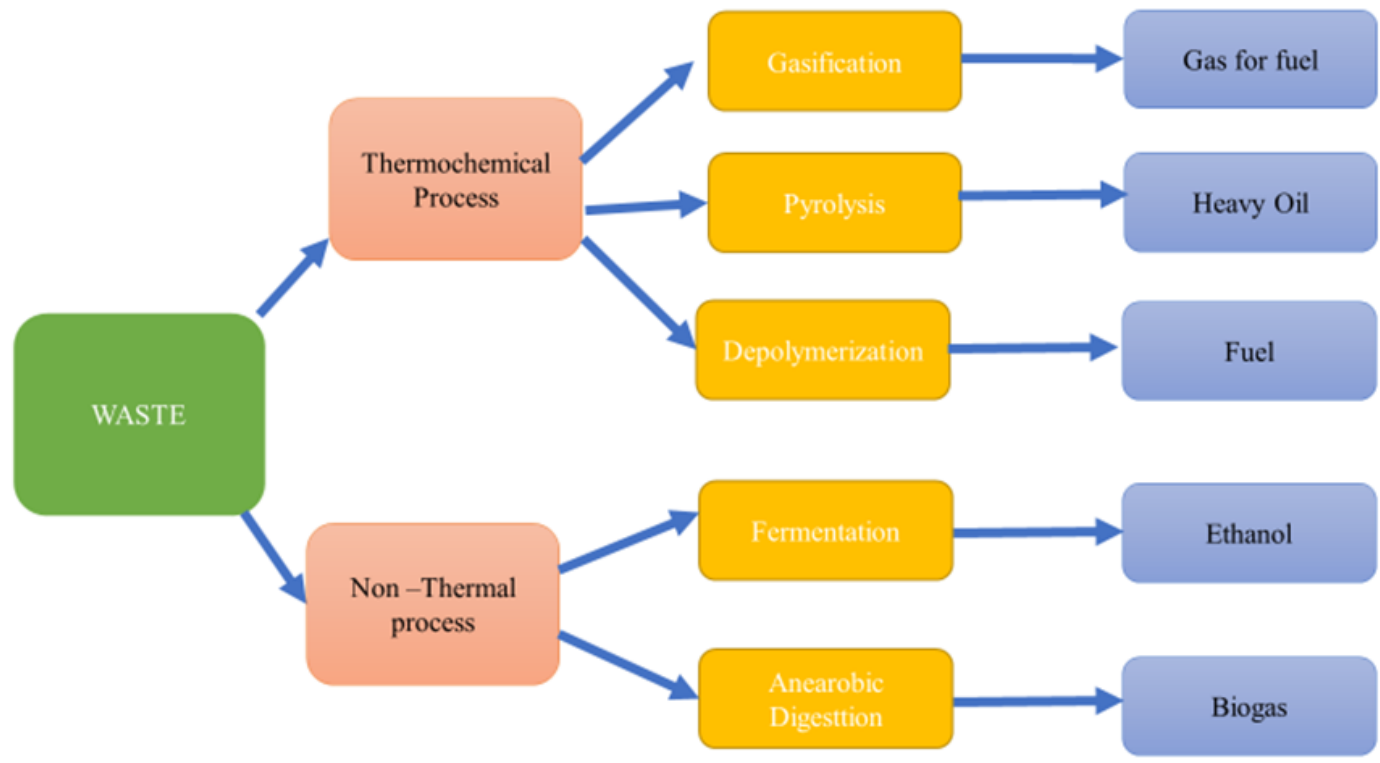

Figure 3. Various processes of energy generation from solid waste and leachate. 


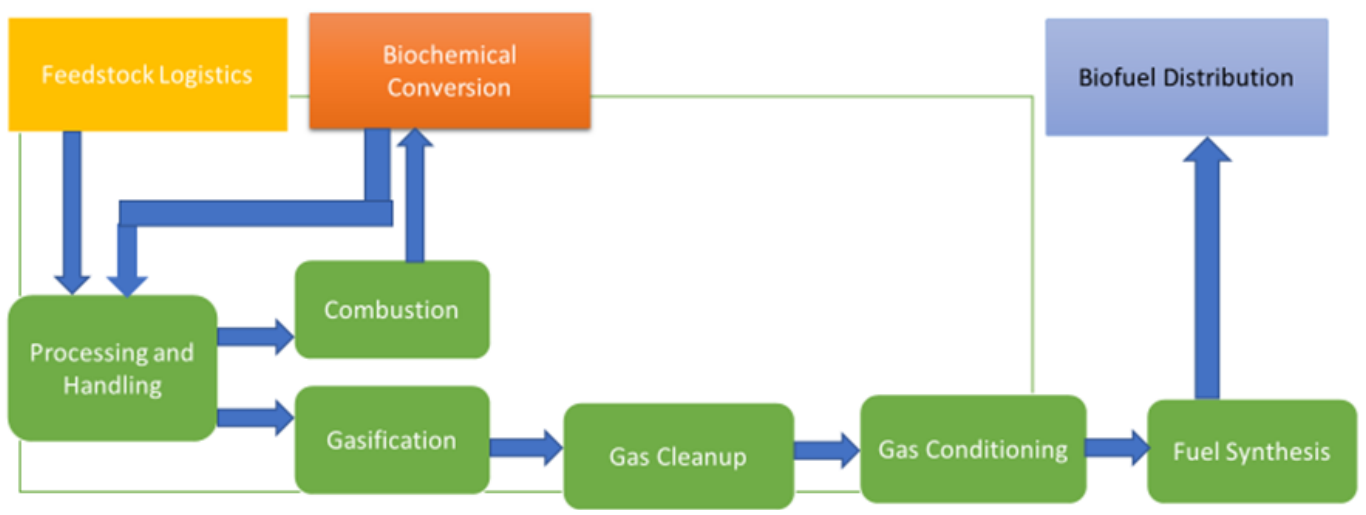

Figure 4. Processes of gasification of solid waste.

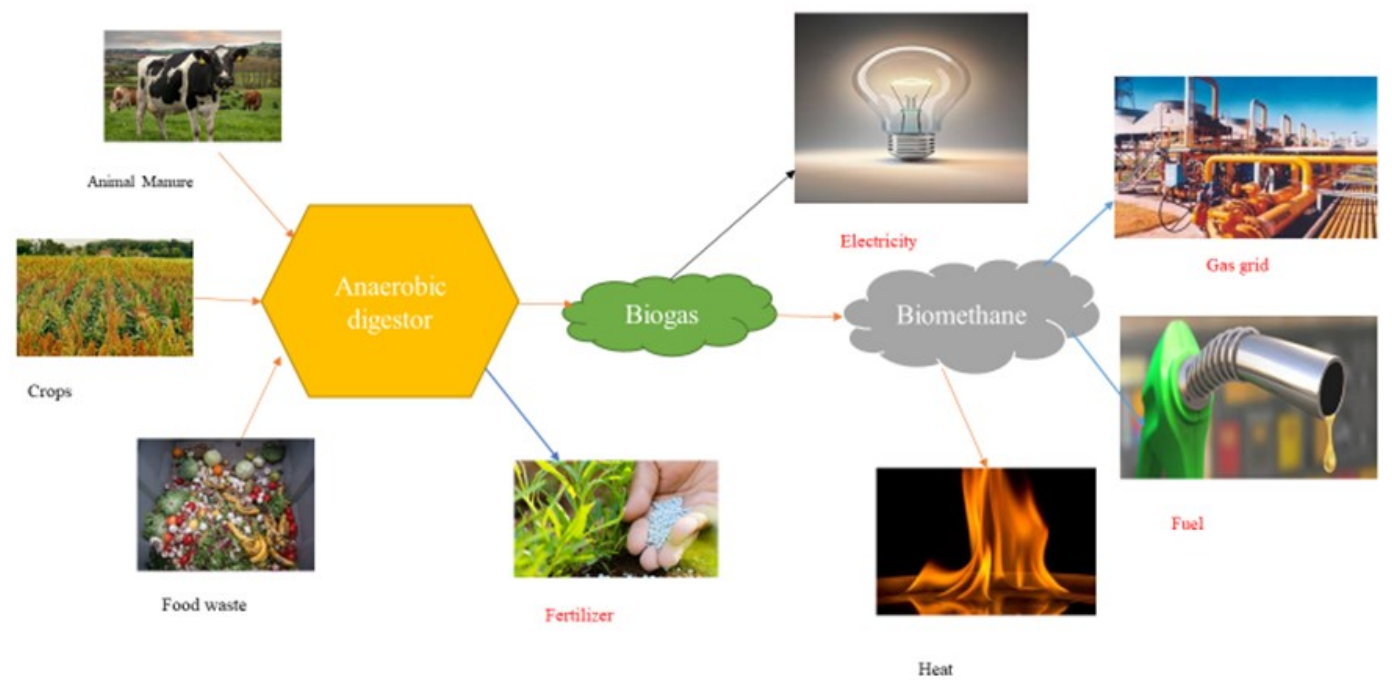

Figure 5. Processes of bioenergy generation from solid waste.

The major problem with this method is that it utilizes liquid trash as well, which does not apply to all the above techniques. It is generally used in small-scale chores as the production depends on the size of the digester or landfill. The biogas provides a clean fuel in the kitchen, and automobile. 50-85\% volume of the waste can be reduced by this process. In many cosmopolitan towns, automatic units have been installed, whereas physically controlled units are established in fairly minor urban places (Bhide and Shekdar, 1998; Kumar et al., 2009). In Bangalore, Baroda, Mumbai, Calcutta, Delhi, Jaipur, Kanpur and Indore, large scale unit were established having the capacity of 150 to 300 tonne/day in 1975- 1980. Later they were closed because of low and minimal use. Subsequently that a large-scale unit was established 
in Mumbai in 1992 having has a capacity of 500 t/day followed by Vijaywada, Bhopal, Delhi, Hyderabad, Bangalore, Ahmedabad, Lucknow, and Gwalior of India (Sharholy et al., 2008; Rao and Shantaram, 1993; Kansal et al., 1998; Reddy and Galab, 1998; Gupta et al., 1998; Srivastava et al., 2005).

\section{Other methods}

Plasma arc gasification: The process uses a plasma torch. Initially in this process, waste is compressed then the plasma torch is utilized to ionize the gas. The product gives Syngas or Synthesis gas which is used to produce electricity (Ojha et al., 2012)

Incineration: It is the most popular process. It is performed by combusting organic garbage. The heat is generated in the process which is used to convert water into steam which is tapped to power turbine to produce electricity (Lee and Huffman, 1989). This plant produces lots of emission of gases like nitrogen oxide, sulphur sulfur dioxide, dioxins, and heavy metals which is a great disadvantage to it. this is one of the reasons for making this technique unpopular these days. Some left-over product from this process is also harmful and need to be handled with care. The drawback of this method is that some harmful compounds like sulphur, nitrogen, and halogens deteriorating air quality are released. Generally scrubbing and filtering are performed to dilute the concentrations to an acceptable level before releasing into the environment (Misra and Pandey, 2005).

Bio-electrochemical systems: Leachate of the landfill also known as landfill leachate has lately been examined as a substratum for bio electrochemical systems (BES) for power generation. The biological complexes in leachate can be directly transformed to electric energy through microbial interface. The recovery of nutrient like ammonia can be done through electricity generation which is driven by ammonium migration and the conversion of ammonium to ammonia in a high-pH which is a result of cathode reduction reaction. Metals in leachate may also be retrieved, but the retrieval is affected by their concentrations and values (Iskander et al., 2016).

\section{Landfill leachate treatment by microalgae}

Solid waste has been expected to grow globally. Right now, the common method is to dump off waste is landfill (Lin et al., 2007). Though, over a significant time leachate is produced which pose serious issue. With growing emphasis on sustainability, there has been a demand for emerging eco-friendly, green treatment schemes for leachates with resource recovery. Microalgae-based methods can be a possible method for such a treatment. The application of algae to eliminate impurities from waste water or leachate is named as phytoremediation (Bordoloi et al., 2020). The study is conducted by many scientists. A relative study was done at three scales i.e. small scale of $0.25 \mathrm{~L}$, medium of $100 \mathrm{~L}$, and large of $1000 \mathrm{~L}$. The bacterial-algal was taken from the pond of fish. The small-scale test was directed in flasks as lot experiments, the medium as well as large-scale experiments were carried out as semi-batch procedures inside a greenhouse in an unrestrained setting with working capacity $60 \%$ of their total 
volume. Kolmogorov-Smirnov statistical tests were functional to the experimental data to regulate if the ammonia elimination, total nitrogen exclusion, and biomass development rate at each scale were diverse (Hernández, 2019). The study demonstrated that there is a substantial change between all rate determined at the large-scale reactors in comparison to that of small-scale reactors. The treatment of leachate with algae require a huge land with appropriate light infiltration and $\mathrm{CO}_{2}$ absorption into the pond. The leachates are often dark brown to grey in colour. The colour affects light penetration undesirably and thus challenges progress of algae. So, it is suggested to use a shallow pond with microalgae. Algae have remained as a 3rd generation biofuel for sometimes now.

\section{Treatment of landfill leachate using reverse osmosis}

The treatment of landfill leachate using reverse osmosis has gained attention in the recent years and many plants have been installed in countries like Germany, the Netherlands and Switzerland. In this system, the landfill leachate can be divided into old and new. They both are further divided into different categories. The new one is toppled in the cell of waste having separate system of collection. A linear correlation is seen among flux and conductivity from the old landfill and from the decomposable waste cell for leachate, where flux varies depending on the conductivity of the leachate. The decrease of contaminants, COD, salt concentration, osmotic pressure comes high. $\mathrm{NH}_{4}-\mathrm{N}$ is also seen in over $98 \%$ for leachate from both old landfill and the biodegradable waste (Chianese et al., 1999; Hasar et al., 2009).

Advantages of resource recovery: Resource recovery helps to preserve the non-renewable reserve which are is reducing at a reckless pace. It is not only a left-over disposing technique, but also supports to handle the garbage. It purposes as substitute to the valuable natural resource and uses the ability that remains in refuse. Two-thirds of carbon dioxide neutral fuel can be used from the left-over. Transformation of waste is a method that is a choice to use oil and other types of energy. A major part of the household waste can be used to generate energy for daily use. It is tactic that can back us to decrease our role in global warming. By harnessing this clean energy, we will reduce our dependence on diminishing fossil fuels.

Disadvantage of resource recovery: The process is proposed for conversion but is constrained to merely specific sorts of waste. Thus, with more upgrading in technologies, transformation methods can be prolonged to use all kinds of waste leaving the toxic ones.

\section{Strategic measures for mitigating the groundwater pollution}

Contamination of groundwater can last for ages but is difficult and expensive to clean. The key is the prevention of pollution. The mitigation measures should be divided into three parts i.e. to be followed at home, at work and in town. At home, basic measures like using less chemicals in forms of detergent, 
shampoo, car cleaner and disposing them properly, also safe storage is important, septic tanks cleaning etc. At work the mitigation measures are carried in three steps. First for hazardous material, second storm water and third is method of waste disposal (discussed in flowchart in detail). And in town it is the duty of all the people living to ensure proper water supplies, also support legislations for protection etc. The common measures which can be followed by everyone are discussed in flowchart.

\section{Conclusion}

Leachate generation is a chief problem of municipal solid waste (MSW) is generation of leachate in landfills. It causes substantial danger to surface water and groundwater. Leachate are formed when water passes through the landfill. Solid waste, biomass residues and leachate are transformed into fuels and bioelectricity, using Thermal Technologies, Non-Thermal Technologies for waste and reverse osmosis, phytoremediation and BES for leachate. The preference of method depends on the product required and the feedstocks. Conventionally, thermochemical technology which utilizes thermal heat may possibly not be susceptible to the biomass waste composition when linked to the biochemical approaches for the manufacture of biofuels. However, the manufacture of biofuels from biomass litter is even believed to be more robust in raw material processing, transport, and transformation skill, when compared to traditional food crops-based biofuels. The process of treatment of leachate are chosen to reduce the contaminants around the landfill and nearby water bodies. A proper understanding of the features of the leachate is expected to be used to select suitable management and economical technique. The effect of leachate on groundwater quality as well as on living being is adverse. The solid waste and leachate both pose threat to environment especially water bodies. As the population is increasing solid waste is also increasing but the water is decreasing. If the landfill site is near the water body, it will affect the water resources. Therefore, it is very important to find an eco-friendly treatment for the waste and leachate treatment which do not affect the environment and the end product can be used as well.

Conflict of interest: The author declares that there is no conflict of interest.

\section{References}

Adams, T.N., Appel, B.S., Einfeldt, C.T. and Freiss, J.H. (2010). Washington, DC: U.S. Patent and Trademark Office.

Agamuthu, P. (2009). Challenges and opportunities in agro-waste management: An Asian perspective. In Inaugural meeting of first regional 3R forum in Asia. pp.11-12.

Alam, P. and Ahmade, K. (2013). Impact of solid waste on health and the environment. International Journal of Sustainable Development and Green Economics, 2(1): 165-168.

Armstrong, M.D. and Rowe, R.K. (1999). Effect of landfill operations on the quality of municipal solid waste leachate. In Proc. 3rd Int. Landfill Symposium. pp. 81-88.

Aziz, H.A. and Amr, S.A. (Eds.). (2016). Control and treatment of landfill leachate for sanitary waste disposal. Hershey: IGI Global. 
Bhalla, B., Saini, M.S. and Jha, M.K. (2013). Effect of age and seasonal variations on leachate characteristics of municipal solid waste landfill. International Journal of Research in Engineering and Technology, 2(8): 223-232.

Bhide, A.D. and Shekdar, A.V. (1998). Solid waste management in Indian urban centres. International Solid Waste Association Times, 1(1): 26-28.

Bordoloi, N., Tiwari, J., Kumar, S., Korstad, J. and Bauddh, K. (2020). Efficiency of Algae for Heavy Metal Removal, Bioenergy Production, and Carbon Sequestration. In Emerging Eco-friendly Green Technologies for Wastewater Treatment. Springer. pp. 77-101.

Botelho Junior, A.B., Jiménez Correa, M.M., Espinosa, D.C.R. and Tenório, J.A.S. (2018). Study of the reduction process of iron in leachate from nickel mining waste. Brazilian Journal of Chemical Engineering, 35(4): 1241-1248.

Boukis, I.P., Grammelis, P., Bezergianni, S. and Bridgwater, A.V. (2007). CFB air-blown flash pyrolysis. Part I: Engineering design and cold model performance. Fuel, 86: 1372-1386.

Bove, D., Merello, S., Frumento, D., Arni, S. A., Aliakbarian, B. and Converti, A. (2015). A critical review of biological processes and technologies for landfill leachate treatment. Chemical Engineering and Technology, 38(12): 2115-2126.

Chen, D., Yin, L., Wang, H. and He, P. (2014). Pyrolysis technologies for municipal solid waste: a review. Waste management, 34(12): 2466-2486.

Cheng, H. and Hu, Y. (2010). Municipal solid waste (MSW) as a renewable source of energy: Current and future practices in China. Bioresource Technology, 101(11): 3816-3824.

Chianese, A., Ranauro, R. and Verdone, N. (1999). Treatment of landfill leachate by reverse osmosis. Water Research, 33(3): 647-652.

Christensen, T.H., Kjeldsen, P., Bjerg, P.L., Jensen, D.L., Christensen, J.B., Baun, A. and Heron, G. (2001). Biogeochemistry of landfill leachate plumes. Applied Geochemistry, 16(7-8): 659-718.

Colon, M. and Fawcett, B. (2006). Community-based household waste management: Lessons learnt from EXNORA's 'zero waste management 'scheme in two South Indian cities. Habitat International, 30(4): 916-931.

Ehrig, H.J. and Robinson, H. (2011). Landfilling: Leachate Treatment in Solid Waste technology and Meanagement. University of Denmark, Lyngby Denmark, pp. 859-897.

El-Fadel, M., Findikakis, A.N. and Leckie, J.O. (1997). Environmental impacts of solid waste landfilling. Journal of Environmental Management, 50(1): 1-25.

Ezirim, I. and Agbo, F. (2018). Role of National Policy in Improving Health Care Waste Management in Nigeria. Journal of Health and Pollution, 8(19): 180913.

Fassell, W.M. (1977). U.S. Patent No. 4,010,098. Washington, DC: U.S. Patent and Trademark Office.

Fatta, D., Papadopoulos, A. and Loizidou, M. (1999). A study on the landfill leachate and its impact on the groundwater quality of the greater area. 21(2): 175-190.

Fjelsted, L., Scheutz, C., Christensen, A.G., Larsen, J.E. and Kjeldsen, P. (2020). Biofiltration of diluted landfill gas in an active loaded open-bed compost filter. Waste Management, 103: 1-11.

Gotvajn, A.Ž., Tišler, T. and Zagorc-Končan, J. (2009). Comparison of different treatment strategies for industrial landfill leachate. Journal of Hazardous Materials. 162(2-3): 1446-1456.

Gupta, S., Mohan, K., Prasad, R., Gupta, S. and Kansal, A. 1998. Solid waste management in India: options and opportunities. Resources, Conservation and Recycling, 24: 137-154

Gyawali, S., Techato, K. and Yuangyai, C. (2012). Effects of industrial waste disposal on the surface water quality of U-tapao River, Thailand. In Proceedings of the 3rd International Conference on Environment Science and Engineering. pp. 109-113.

Hamilton, L.C. (1985). Concern about toxic wastes: Three demographic predictors. Sociological Perspectives, 28(4): $463-486$.

Hasar, H., Unsal, S.A., Ipek, U., Karatas, S., Cınar, O., Yaman, C. and Kınacı, C. (2009). Stripping/flocculation/membrane 
bioreactor/reverse osmosis treatment of municipal landfill leachate. Journal of Hazardous Materials, 171(1-3): 309-317.

Havlicek, J., Richardson, R. and Davies, L. (1971). Measuring the impacts of solid waste disposal site location on property values, 2183: 2019-979.

Hay, J.X.W., Wu, T.Y., Juan, J.C. and Md. Jahim, J. (2013). Biohydrogen production through photo fermentation or dark fermentation using waste as a substrate: overview, economics, and future prospects of hydrogen usage. Biofuels, Bioproducts and Biorefining, 7(3): 334-352.

He, J., Wang, Y., Li, Y. and Ruan, X.C. (2015). Effects of leachate infiltration and desiccation cracks on hydraulic conductivity of compacted clay. Water Science and Engineering, 8(2): 151-157.

Hernández-García, A., Velásquez-Orta, S.B., Novelo, E., Yáñez-Noguez, I., Monje-Ramírez, I. and Ledesma, M.T.O. (2019). Wastewater-leachate treatment by microalgae: Biomass, carbohydrate and lipid production. Ecotoxicology and Environmental safety. 174: 435-444.

Hernández-García, A., Velásquez-Orta, S.B., Novelo, E., Yáñez-Noguez, I., Monje-Ramírez, I. and Ledesma, M.T.O. (2019). Wastewater-leachate treatment by microalgae: Biomass, carbohydrate and lipid production. Ecotoxicology and Environmental Safety, 174: 435-444.

Hester, R.E. and Harrison, R.M. (Eds.). (2002). Environmental and health impact of solid waste management activities. Royal Society of Chemistry, 2(18): 1-10.

Hickman, H.L. (2003). American alchemy: the history of solid waste management in the United States. Forester Press.

Hoornweg, D. and Bhada Tata, P. (2012). What a waste?: a global review of solid waste management. The World Bank. No. 68135, pp. 1-116.

Hwang, I.H., Matsuto, T., Tanaka, N., Sasaki, Y. and Tanaami, K. (2007). Characterization of char derived from various types of solid wastes from the standpoint of fuel recovery and pretreatment before landfilling. Waste Management, 27(9): $1155-1166$.

Iskander, S.M., Brazil, B., Novak, J.T. and He, Z. (2016). Resource recovery from landfill leachate using bioelectrochemical systems: opportunities, challenges, and perspectives. Bioresource Technology, 201: 347-354.

Jambeck, J.R., Geyer, R., Wilcox, C., Siegler, T.R., Perryman, M., Andrady, A. and Law, K. L. (2015). Plastic waste inputs from land into the ocean. Science. 347(6223): 768-771.

Jecu, L. (2000). Solid state fermentation of agricultural wastes for endoglucanase production. Industrial Crops and Products, 11 (1): $1-5$.

Joardar, S.D. (2000). Urban residential solid waste management in India: Issues related to institutional arrangements. Public Works Management and Policy, 4(4): 319-330.

Kansal, A., Prasad, R.K. and Gupta, S. (1998). Delhi municipal solid waste and environment-an appraisal. Indian Journal of Environmental Protection, 18(2): 123-128.

Kettunen, R.H. and Rintala, J.A. (1998). Performance of an on-site UASB reactor treating leachate at low temperature. Water Research, 32(3): 537-546.

Kettunen, R.H., Hoilijoki, T.H. and Rintala, J.A. (1996). Anaerobic and sequential anaerobic-aerobic treatments of municipal landfill leachate at low temperatures. Bioresource Technology, 58(1): 31-40.

Kjeldsen, P., Barlaz, M.A., Rooker, A.P., Baun, A., Ledin, A. and Christensen, T.H. (2002). Present and long-term composition of MSW landfill leachate: a review. Critical Reviews in Environmental Science and Technology, 32(4): 297-336.

Klinck, B.A. and Stuart, M.E. (1999). Human health risk in relation to landfill leachate quality. British Geological Survey, Technical Report, 99(17): 1-10.

Kulikowska, D. and Klimiuk, E. (2008). The effect of landfill age on municipal leachate composition. Bioresource Technology, 99 (13): 5981-5985.

Kumar, P., Kumar, V., Kumar, S., Singh, J. and Kumar, P. (2020a). Bioethanol production from sesame (Sesamum indicum L.) 
plant residue by combined physical, microbial and chemical pretreatments. Bioresource Technology, 297: 122484.

Kumar, S., Bhattacharyya, J., Vaidya, A., Chakrabarti, T., Devotta, S. and Akolkar, A. (2009). Assessment of the status of municipal solid waste management in metro cities, state capitals, class I cities, and class II towns in India: An insight. Waste Management, 29: 883-89

Kumar, S., Dhar, H., Nair, V.V., Bhattacharyya, J.K., Vaidya, A.N. and Akolkar, A.B. (2016). Characterization of municipal solid waste in high-altitude sub-tropical regions. Environmental Technology, 37(20): 2627-2637.

Kumar, V., Kumar, P., Kumar, P. and Singh, J. (2020b). Anaerobic digestion of Azolla pinnata biomass grown in integrated industrial effluent for enhanced biogas production and COD reduction: Optimization and kinetics studies. Environmental Technology \& Innovation, 17: 100627.

Lee, A.H., Nikraz, H. and Hung, Y.T. (2010). Influence of waste age on landfill leachate quality. International Journal of Environmental Science and Development, 1(4): 347.

Lee, C.C. and Huffman, G.L. (1989). Incineration of solid waste. Environmental Progress, 8(3): 143-151.

Lee, S.H., Themelis, N.J. and Castaldi, M.J. (2007). High-temperature corrosion in waste-to-energy boilers. Journal of Thermal Spray Technology: 16(1): 104-110.

Lens, P., Hamelers, B., Hoitink, H. and Bidlingmaier, W. (Eds.). (2004). Resource recovery and reuse in organic solid waste management. IWA publishing.

Lin, L., Chan, G.Y.S., Jiang, B.L. and Lan, C.Y. (2007). Use of ammoniacal nitrogen tolerant microalgae in landfill leachate treatment. Waste Management, 27(10): 1376-1382.

Lussiez, G.W. (1993). Treating water-reactive wastes (No. LA-UR-93-1204; CONF-930873-9). Los Alamos National Lab., NM (United States).

Malviya, R. and Chaudhary, R. (2006). Factors affecting hazardous waste solidification/ stabilization: A review. Journal of Hazardous Materials, 137(1): 267-276.

Malviya, R.; Chaudhary, R. and Buddhi, D. (2002). Study on solid waste assessment and management-Indore city. Indian Journal of Environmental Protection, 22(8): 841-846.

Mishra, H., Karmakar, S., Kumar, R. and Kadambala, P. (2018). A long-term comparative assessment of human health risk to leachate-contaminated groundwater from heavy metal with different liner systems. Environmental Science and Pollution Research, 25(3): 2911-2923.

Misra, V. and Pandey, S.D. (2005). Hazardous waste, impact on health and environment for development of better waste management strategies in future in India. Environment International, 31: 417-431.

Mor, S., Ravindra, K., Dahiya, R.P. and Chandra, A. (2006). Leachate characterization and assessment of groundwater pollution near municipal solid waste landfill site. Environmental Monitoring and Assessment, 118(1-3): 435-456.

Munawar, E., Yunardi, Y., Lederer, J. and Fellner, J. (2018). The development of landfill operation and management in Indonesia. Journal of Material Cycles and Waste Management, 20(2): 1128-1142.

Nema, A.K. (2004). Collection and transport of municipal solid waste. Training program on solid waste management. Springer.

Nika, M.C., Ntaiou, K., Elytis, K., Thomaidi, V.S., Gatidou, G., Kalantzi, O.I. and Stasinakis, A.S. (2020). Wide-scope target analysis of emerging contaminants in landfill leachates and risk assessment using Risk Quotient methodology. Journal of Hazardous Materials, 122493.

Orloff, K. and Falk, H. (2003). An international perspective on hazardous waste practices. International Journal of Hygiene and Environmental Health, 206(4-5): 291-302.

Purwanta, W. (2007) Leachate Treatment Technology Review in Landfills (Landfill). MSW, 3(1): 1-10.

Raghab, S.M., Abd El Meguid, A.M. and Hegazi, H.A. (2013). Treatment of leachate from municipal solid waste landfill. HBRC Journal, 9(2): 187-192. 
Rao, K. and Shantaram, M. (1993). Physical characteristics of urban solid wastes of Hyderabad. Indian Journal of Environmental Protection, 13: 425-721.

Raza, G., Dutt, B. and Singh, S. (1997). Kaleidoscoping public understanding of science on hygiene, health and plague: a survey in the aftermath of a plague epidemic in India. Public Understanding of Science, 6(3): 247-268.

Reddy, S. and Galab, S. (1998). An integrated economic and environmental assessment of solid waste management in India The Case of Hyderabad. India. (nd).

Reinhart, D.R. and Basel Al-Yousfi, A. (1996). The impact of leachate recirculation on municipal solid waste landfill operating characteristics. Waste Management and Research, 14(4): 337-346.

Renou, S., Givaudan, J.G., Poulain, S., Dirassouyan, F. and Moulin, P. (2008). Landfill leachate treatment: Review and opportunity. Journal of Hazardous Materials, 150(3). 468-493.

Saarela, J. (2003). Pilot investigations of surface parts of three closed landfills and factors affecting them. Environmental Monitoring and Assessment, 84(1-2): 183-192.

Sawhill, J.W., Freeman, L.D. and McKinney, C. (1995). U.S. Patent No. 5,384,092. Washington, DC: U.S. Patent and Trademark Office.

Schoenberger, R.J., Corbin, M.H., Wittmer, S.J. and Lenthe, A.L. (1984). Thermal destruction of ignitable hazardous waste. A case study in regulatory interpretation. In Proceedings 39 th Industrial Waste Conference. Purdue University. pp. 447452.

Sharholy, M., Ahmad, K., Mahmood, G. and Trivedi, R.C. (2008). Municipal solid waste management in Indian cities-A review. Waste Management, 28(2): 459-467.

Singh, A., Chandra, S., Gupta, S.K., Chauhan, L.K.S. and Rath, S.K. (2007). Mutagenicity of leachates from industrial solid wastes using Salmonella reverse mutation assay. Ecotoxicology and Environmental Safety, 66(2): 210-216.

Singh, R.P., Tyagi, V.V., Allen, T., Ibrahim, M.H. and Kothari, R. (2011). An overview for exploring the possibilities of energy generation from municipal solid waste (MSW) in Indian scenario. Renewable and Sustainable Energy Reviews, 15(9): 4797-4808.

Skrinde, J.R. and Bhagat, S.K. (1982). Industrial wastes as carbon sources in biological denitrification. Journal of Water Pollution Control Federation, 370-377.

Srivastava, P., Kulshreshtha, K., Mohanty, C., Pushpangadan, P. and Singh, A. (2005). Stakeholder-based SWOT analysis for successful municipal solid waste management in Lucknow, India. Waste Management, 25: 531-537

Turan, N.G., Mesci, B. and Ozgonenel, O. (2011). The use of artificial neural networks (ANN) for modeling of adsorption of $\mathrm{Cu}$ (II) from industrial leachate by pumice. Chemical Engineering Journal. 171(3): 1091-1097.

Welander, U., Henrysson, T. and Welander, T. (1998). Biological nitrogen removal from municipal landfill leachate in a pilot scale suspended carrier biofilm process. Water Research, 32(5): 1564-1570.

Weng, J., Jia, L., Sun, S., Wang, Y., Tang, X., Zhou, Z. and Qi, F. (2013). On-line product analysis of pine wood pyrolysis using synchrotron vacuum ultraviolet photoionization mass spectrometry. Analytical and Bioanalytical Chemistry, 405(22): 7097-7105.

Zhao, R. (2012). Management strategy of landfill leachate and landfill gas condensate (Doctoral dissertation, Virginia Tech).

Cite this chapter as: Kamboj, N., Bisht, A., Kamboj, V. and Bisht, A. (2020). Leachate disposal induced groundwater pollution: A threat to drinking water scarcity and its management. In: Advances in Environmental Pollution Management: Wastewater Impacts and Treatment Technologies, Volume 1, Eds. Kumar, V., Kamboj, N., Payum, T., Singh, J. and Kumar, P., pp. 54-76, https://doi.org/10.26832/aesa-2020-aepm-05 